\title{
Pemberian makanan F100 dengan bahan substitusi tepung tempe terhadap status protein pasien anak dengan gizi kurang
}

Effect of F100 supplementation using substitute tempeh flour on protein status of undernourished pediatric patients

Diniyah Kholidah ${ }^{1}$, Endy Paryanto Prawirohartono ${ }^{2}$, Fatma Zuhrotun Nisa ${ }^{3}$

\begin{abstract}
Background: Much effort has been made to counter the weaknesses of F100 through the development of milk powder substituted with ingredients that have a high content of protein and energy, high bioavailability and relatively low cost. Objective: To analyze effect of F100 supplementation using substitute tempeh flour on protein status (total protein serum and serum albumin) among undernourished pediatric patients. Method: Experimental research with randomized clinical control trial among 30 undernourished children consisting of open clinical trial in two experiment groups, supplemented with F100 or substitute F100 (isoenergetic and isoprotein diet) within 14 days. The study was undertaken in April-August 2010 at pediatric inpatient room of Dr. Saiful Anwar Hospital Malang. Data of food intake were obtained through visual comstock and 24 hour food recall; data of total serum protein through biuret method; serum albumin (Alb) through cellulose acetate electrophoresis method. Data analysis was using Pearson Chi-Square test and unpaired t-test. Results: The result of unpaired t-test on average intake of energy, protein, fat and carbohydrate showed there was no significant difference in each experimental groups ( $p>0.05)$. The test result of total serum protein level and serum Alb level showed there was no significant difference in each experiment $(p=0.240$ and $p=0.774)$. The result of correlation coefficient test showed there was no significant association between intake of energy and nutrient and total serum level and serum Alb level ( $p>0.05)$ and degree of association showed a weak association ( $r>0.25)$. Conclusion: Formula of F100 substitute as complementary food could be used as an alternative food in diet therapy of malnourished children on rehabilitation phase.
\end{abstract}

KEY WORDS: malnutrition, F100, substitute F100, total serum protein, serum albumin

\begin{abstract}
ABSTRAK
Latar belakang: Berbagai upaya telah dilakukan untuk menutup kelemahan F100 melalui pengembangan bahan substitusi sumber lemak atau protein dengan bahan makanan yang mempunyai kandungan energi dan zat gizi, bioavailabilitas tinggi, serta relatif murah. Tujuan: Menganalisis pengaruh pemberian makanan F100 dengan bahan substitusi tepung tempe terhadap status protein (serum protein total dan albumin serum) pasien anak dengan gizi kurang. Metode: Penelitian eksperimental dengan randomized clinical control trial pada 30 anak kurang gizi yaitu uji klinis open trial dua kelompok perlakuan, pemberian F100 dan substitusi F100 (isokalori dan isoprotein) selama 14 hari. Penelitian dilakukan pada bulan April - Agustus 2010 di ruang Rawat Inap Anak RSU Dr. Saiful Anwar Malang. Data asupan makanan menggunakan visual comstock dan 24 hour food recall. Data protein serum total menggunakan metode biuret dan albumin (Alb) serum menggunakan metode celulose acetate electrophoresis. Analisis data menggunakan uji Pearson Chi-Square dan unpaired t-test. Hasil: Hasil uji unpaired t-test rerata asupan energi, protein, lemak, dan karbohidrat menunjukkan tidak terdapat perbedaan bermakna antar perlakuan $(\mathrm{p}>0,05)$. Hasil uji kadar protein serum total dan kadar Alb serum menunjukkan tidak terdapat perbedaan bermakna antar perlakuan ( $p=0,240$ dan $p=0,774)$. Hasil uji koefisien korelasi menunjukkan tidak terdapat hubungan yang bermakna antara asupan energi dan zat gizi dengan kadar protein serum total dan kadar Alb serum ( $p>0,05)$ dan derajat keeratan hubungan yang lemah ( $r>0,25)$. Simpulan: Formula substitusi F100 sebagai makanan tambahan dapat digunakan sebagai makanan alternatif dalam terapi diit anak malnutrisi fase rehabilitasi.
\end{abstract}

KATA KUNCI: malnutrisi, F100, substitusi F100, kadar protein serum total, kadar albumin serum

\section{PENDAHULUAN}

Spektrum malnutrisi anak baik individu atau populasi memerlukan pengelolaan secara intensif baik klinis maupun makanannya terutama pada pasien yang tidak biasa mentoleransi protein dalam jumlah normal. World Health Organization (WHO) merekomendasikan formula makanan terstandar untuk penanganan malnutrisi pada fase stabilisasi, transisi, dan rehabilitasi yaitu berupa

\footnotetext{
${ }^{1}$ Korespondensi: Jurusan Gizi, Politeknik Kesehatan Kementerian Kesehatan Malang, Jl. Besar Ijen 77 C Malang, e-mail: dini_2109@yahoo.com Imu Kesehatan Anak, Rumah Sakit Umum Pusat Dr. Sardjito, Jl. Kesehatan No.1, Yogyakarta 55281,e-mail: prawirohartonoendypyt@yahoo.co.id

Program Studi Gizi Kesehatan, Fakultas Kedokteran Universitas Gadjah Mada, Jl. Farmako, Sekip Utara, Yogyakarta 55281
} 
formula (F75, F100, F135) yang merupakan formula standar WHO dengan bahan dasar bubuk susu skim dan telah dikembangkan berbagai modifikasinya (1).

Bagi masyarakat negara berkembang khususnya masyarakat pedesaan, susu masih merupakan bahan makanan yang relatif sulit didapatkan, relatif mahal, dan daya beli masyarakat rendah. Menambahkan 10$15 \%$ bubuk susu akan meningkatkan biaya dua kali lipat sehingga perlu dikembangkan berbagai formula alternatif terutama pada kelompok pasien anak dengan intoleransi susu $(2,3)$. Susu menyebabkan diare pada anak lactose intolerance dan alergi susu disebabkan tidak adanya enzim laktase yang mencerna gula susu (laktosa) menjadi glukosa dan galaktosa (4-6). Oleh karena itu, penggantian susu diperlukan sebagai alternatif formula penanganan gizi buruk (sebagai terapi diit regular fase rehabilitasi) yang dapat meningkatkan berat badan serta pengganti susu sapi pada pasien anak dengan lactose intolerance, diare, dan pasien yang tidak bisa minum susu.

Beberapa penelitian pengembangan formula 100 (F100), menganalisis keefektifan F100 yang telah direkomendasikan oleh WHO yaitu menggunakan mentega kacang tanah, bubur sereal, dan bubur tepung jagung dan sudah dikembangkan di beberapa negara sebagai bentuk alternatif penanganan gizi buruk (4,7-9). Salah satu upaya menutup kelemahan F100 dilakukan dengan pengembangan bahan substitusi sumber lemak atau protein dengan bahan makanan yang mempunyai kandungan energi dan zat gizi, bioavailabilitas tinggi (seimbang dengan telur dan susu), mudah didapat, dan relatif murah. Salah satu alternatif bahan makanan tersebut adalah tepung tempe kedelai. Namun, penelitian yang menguji pengaruh metabolik dan status gizi secara biokimiawi penambahan susu formula standar dan membandingkan substitusinya (tepung tempe kedelai) masih terbatas. Penelitian ini menguji hipotesis bahwa formula substitusi F100 (FS100) dengan menggunakan bahan substitusi tepung tempe tidak berbeda dengan F100 dalam hal pemenuhan asupan energi dan zat gizi serta status protein. Status protein yang digunakan berupa kadar protein serum total dan kadar albumin serum sebagai salah satu prediktor akurat dan sensitif dalam evaluasi pasien malnutrisi pada fase rehabilitasi.

\section{BAHAN DAN METODE}

Penelitian ini merupakan penelitian eksperimental tentang pemberian makanan substitusi F100 terhadap status protein (protein serum total dan albumin serum) pada anak gizi kurang di Rumah Sakit Umum (RSU) Dr. Saiful Anwar Malang. Rancangan penelitian yang digunakan adalah randomized control clinical trial yaitu uji klinis dengan kontrol random yang bersifat open trial dengan dua kelompok perlakuan yaitu F100 dan FS100 yang isokalori dan isoprotein. Alokasi subjek penelitian dilakukan untuk menentukan 30 subjek menggunakan sistem random sampling dengan bantuan tabel bilangan random (tabel bilangan acak). Jenis-jenis intervensi yang akan dirandomisasi pada tingkat individu dialokasikan dengan metode alokasi rasio 1:1. Dalam randomisasi ini menggunakan rancangan acak kelompok (randomized block design) yaitu terdapat kesetaraan jumlah subjek yang terdistribusi pada masing-masing kelompok.

Penelitian dilakukan pada bulan April sampai dengan Agustus 2010 di Instalasi Rawat Inap IV (IRNA IV) SMF Ilmu Kesehatan Anak (IKA) RSU Dr. Saiful Anwar Malang dan Laboratorium Central RSU Dr. Saiful Anwar Malang untuk pemeriksaan status protein. Populasi terjangkau dalam penelitian ini adalah anakanak gizi kurang berdasarkan pengukuran antropometri di IRNA IV SMF IKA RSU Dr. Saiful Anwar Malang pada bulan April - Agustus 2010. Besar sampel untuk penelitian analitis numerik tidak berpasangan dihitung menggunakan rumus (10) dengan standar deviasi $(\sigma)$ outcome protein serum total sebesar $6,9 \mathrm{~g} / \mathrm{L}$ dan albumin serum sebesar $0,6 \mathrm{mg} / \mathrm{dl}(11)$; tingkat kemaknaan $\left(\mathrm{Z}_{\alpha}\right)$ sebesar 1,960; power yang diinginkan sebesar $90 \%$; serta selisih mean outcome kelompok antarintervensi untuk protein serum total sebesar $8,1 \mathrm{~g} / \mathrm{L}$ dan albumin serum sebesar $0,7 \mathrm{mg} / \mathrm{dl}$ (11) sehingga dibutuhkan 15 orang untuk setiap kelompok perlakuan.

Subjek penelitian adalah pasien gizi kurang yang ditemukan selama 5 bulan penelitian dengan kriteria inklusi yaitu anak berusia $1-10$ tahun, nilai z skor berat badan menurut tinggi badan (BB/TB) lebih besar dari -3 SD sampai dengan kurang dari -2 SD sesuai standar World Health Organization-National Center for Health Statistics (WHO-NCHS), suka atau mau minum susu, tanpa riwayat lactose intolerance (data rekam medis 
pasien), tanpa terapi suplemen albumin, mendapatkan diit oral (makanan standar rumah sakit), serta bersedia menjadi subjek penelitian dengan menandatangani proxy consent oleh orang tua atau pengasuh. Proxy consent adalah suatu pernyataan sepihak yang diberikan oleh orang tua yang bukan menjadi subjek penelitian dan isinya berupa izin atau persetujuan kepada peneliti untuk melakukan intervensi sesudah orang yang berhak tersebut diberikan informasi secukupnya. Sementara itu, kriteria eksklusi yaitu subjek dengan penyakit hati, penyakit ginjal, penyakit keganasan, dan protein loosing enteropathy.

Penelitian pendahuluan dengan melakukan uji laboratorium berupa pengolahan F100 dan FS100, pengolahan formula susu standar RS dan pengolahan F100 sesuai unit eksperimen yang telah ditetapkan, serta pengukuran kadar air, kadar abu, kadar protein, kadar lemak, dan viskositas dilakukan di Laboratorium Ilmu Bahan Makanan dan Laboratorium Kimia Jurusan Gizi Politeknik Kesehatan Kemenkes Malang. Penentuan bioavailabilitas protein secara in vitro dilakukan di Laboratorium Kimia Pangan - Balai Penelitian Tanaman Kacang-kacangan dan Umbi-umbian Malang. Subjek pada kelompok $\mathrm{P}_{1}$ diberikan makanan standar rumah sakit dengan ekstra F100 dan kelompok $\mathrm{P}_{2}$ diberikan makanan standar rumah sakit dengan ekstra FS100, masing-masing dengan frekuensi 3 kali setiap hari sebanyak $200 \mathrm{ml}$ untuk sekali pemberian selama 14 hari observasi (Tabel 1).
Variabel bebas dalam penelitian ini adalah jenis makanan (F100 dan FS100) dan variabel tergantungnya adalah status protein (kadar protein total serum dan kadar albumin serum). Asupan makan pasien diperoleh dari pengamatan sisa makanan pasien setiap waktu makan dengan menggunakan formulir visual comstock untuk pengamatan selama di rumah sakit sedangkan asupan makan pasien dari luar rumah sakit atau di rumah diperoleh dengan food recall menggunakan formulir recall 24 jam.

Data status protein diperoleh dari hasil pemeriksaan darah subjek yaitu kadar protein serum total dengan metode Biuret (Weichelbaum) dan kadar albumin serum dengan metode celulose acetate electrophoresis. Pemeriksaan darah dilakukan di Laboratorium Patologi Klinik RSU Dr. Saiful Anwar Malang oleh petugas paramedis serta diukur sebelum dan sesudah intervensi (jarak waktu 14 hari). Jumlah hari yang dibutuhkan untuk memperkirakan konsumsi protein menggunakan rumus $\mathrm{n}=\left(\mathrm{Z}_{\alpha} \mathrm{CV}_{\omega} / \mathrm{D}_{0}\right)^{2}(12)$ dengan tingkat kemaknaan $\left(\mathrm{Z}_{\alpha}\right)=1,960$; koefisien variasi antarindividu $\left(\mathrm{CV}_{\omega}\right)$ pada anak usia 1-11 tahun sebesar 33,0\%; dan batas spesifik $\left(\mathrm{D}_{0}\right)$ persentase waktu konsumsi yang bisa ditoleransi sebesar 17,5\%. Berdasarkan perhitungan tersebut, maka pemberian intervensi dilakukan selama 14 hari dengan mempertimbangkan daya terima bahan intervensi dan masa paruh waktu kadar albumin serum.

Data antropometri BB/TB diketahui dengan penimbangan berat badan menggunakan timbangan injak

Tabel 1. Komposisi formula dan kandungan zat gizi pada setiap perlakuan (dalam $100 \mathrm{ml} /$ penyajian)

\begin{tabular}{lccccc}
\hline \multirow{2}{*}{$\begin{array}{c}\text { Komposisi } \\
\text { penyusun }\end{array}$} & $\begin{array}{c}\text { Berat } \\
\text { (g) }\end{array}$ & $\begin{array}{c}\text { Energi } \\
\text { (kcal) }\end{array}$ & $\begin{array}{c}\text { Protein } \\
\text { (g) }\end{array}$ & $\begin{array}{c}\text { Lemak } \\
\text { (g) }\end{array}$ & $\begin{array}{c}\text { Karbohidrat } \\
\text { (g) }\end{array}$ \\
\hline F100 & & & & & \\
$\quad$ Susu skim & 8,5 & 30,8 & 3,0 & 0,1 & 4,4 \\
Gula pasir & 5 & 18,2 & 0,0 & 0,0 & 4,7 \\
Minyak kelapa & 6 & 52,2 & 0,1 & 5,9 & 0,0 \\
Elektrolit & 2 & & & & \\
Air & 100 & & 3,1 & 6,0 & 9,1 \\
Jumlah & & 101,2 & & & \\
FS100 & & & 3,0 & 2,0 & 4,2 \\
Tepung tempe & 6,8 & 47,1 & 0,0 & 0,0 & 2,8 \\
Gula pasir & 3 & 10,9 & 0,1 & 4,9 & 0,0 \\
Minyak kelapa & 5 & 43,5 & & & \\
Elektrolit & 2 & & 3,1 & 6,9 & 7,0 \\
Air & 100 & & 101,5 & 3,9 & \\
Jumlah & & &
\end{tabular}

Keterangan: Kandungan gizi F100 dan FS100 diperoleh dari perhitungan berdasarkan Daftar Komposisi Bahan Makanan (DKBM) 
merek Smic yang memiliki ketelitian $0,1 \mathrm{~kg}$. Subjek diukur pada posisi berdiri tegak tepat di tengah timbangan, tanpa menggunakan alas kaki, dan pembacaan angka dilakukan setelah jarum penunjuk tidak bergerak. Selanjutnya, tinggi badan diukur menggunakan microtoise merek Smic dengan ketelitian $0,1 \mathrm{~cm}$. Subjek diukur dalam posisi berdiri tegak dengan pandangan menghadap lurus ke depan tanpa menggunakan alas kaki.

Uji statistik untuk mengetahui perbedaan proporsi karakteristik dasar antar perlakuan menggunakan uji Pearson Chi-Square $(\alpha=0,05)$. Karakteristik status protein dianalisis dengan menggunakan uji statistik unpaired t-test dan uji kesamaan varian pada taraf signifikansi yang sama. Perbedaan status protein dan asupan makanan antarkelompok perlakuan diketahui dengan melihat distribusi data outcome. Plot (scatter) dilakukan untuk melihat perbedaan data dan menentukan outlier. Apabila sebaran data outcome terdistribusi normal menurut uji normalitas Shapiro Wilk, maka dilakukan analisis bivariat dengan menggunakan uji statistik unpaired t-test untuk melihat perbedaan antarkelompok perlakuan $(\alpha=0,05)$. Analisis hubungan antarvariabel dengan menggunakan uji koefisien korelasi sedangkan analisis multivariat dengan menggunakan regresi linier untuk mengetahui variabel yang paling berpengaruh. Teknik analisis data dilakukan dengan menggunakan software komputer SPSS 12. Ethical clearance diperoleh dari Komisi Etik Penelitian Kedokteran dan Kesehatan Fakultas Kedokteran Universitas Gadjah Mada Yogyakarta.

\section{HASIL}

Hasil uji laboratorium pendahuluan berupa pengembangan F100 dengan substitusi tepung tempe menghasilkan pencampuran bahan formula berwarna putih kekuningan dan beraroma khas tempe. Aroma khas tempe relatif sulit dihilangkan meskipun telah dilakukan perlakuan blanching sebelum pengeringan. Aroma khas tempe disebabkan adanya oksidasi asam lemak linoleat oleh enzim lipoksigenase (lipoksidase). Sementara itu, kedelai merupakan sumber utama enzim lipoksidase (13). Proses pengolahan dengan menggunakan pengeringan suhu tinggi (microwave selama 15 menit) pada FS100 yang menggunakan bahan makanan lokal dapat meningkatkan rasa (lebih gurih) sehingga dapat diterima oleh anak-anak yang diketahui berdasarkan analisis daya terima FS100. Proses pengeringan dengan microwave yang dilakukan selama 10 menit dapat meningkatkan daya simpan formula yaitu 10 hari berdasarkan hitung koloni. Proses pengeringan tersebut tidak menyebabkan perubahan kandungan energi, protein, dan lemak. Proses pengeringan dengan microwave menyebabkan terjadinya penurunan kadar air dari 5,73\% menjadi 3,72\% yang juga mengakibatkan peningkatan jumlah padatan per satuan berat atau peningkatan nilai gizi per satuan berat.

FS100 menghasilkan kepadatan nutrisi dengan densitas kalori 2 kali lebih besar dibandingkan F100, maka dapat diberikan $100 \mathrm{ml}$ setiap kali intervensi sehingga tidak menyebabkan rasa kenyang. Meskipun demikian, kedua formula intervensi memiliki rasio yang sama dalam hal komposisi energi (isoenergi). FS100 selain dapat dikonsumsi dengan penambahan air, juga dapat dikonsumsi tanpa penambahan air (dimakan langsung) oleh anak. Hal tersebut dapat mengeliminasi risiko kontaminasi bakteri terutama jika dikonsumsi di rumah. Penelitian di Senegal (7) membandingkan manfaat ready-to-use therapeutic food (RTUF) yang mengganti bahan susu skim pada F100 dengan selai kacang. Formula ini memiliki densitas kalori lebih dari 5 kali dibandingkan F100 dengan rasio komposisi kalori yang sama. RTUF dapat dikonsumsi dengan atau tanpa penambahan air dan dapat dipertimbangkan sebagai referensi diit pada fase rehabilitasi dan direkomendasikan secara luas untuk digunakan dalam masyarakat.

Subjek dalam penelitian ini berjumlah 36 anak yang dirawat di SMF IKA RSU Dr. Saiful Anwar Malang selama bulan April sampai dengan Agustus 2010. Dua puluh anak diberikan formula standar $\mathrm{F} 100\left(\mathrm{P}_{1}\right)$ dan 16 anak diberikan formula substitusi F100 $\left(\mathrm{P}_{2}\right)$. Lima orang drop out pada kelompok $\mathrm{P}_{1}$ karena penyakit pasien yang tidak memungkinkan dilakukan pengambilan darah, menolak dilakukan home visite (home visite dilakukan jika waktu pemberian intervensi di RS kurang dari 14 hari), menolak melanjutkan konsumsi F100, dan menolak dilakukan posttest. Satu orang drop out pada kelompok $\mathrm{P}_{2}$ karena pasien menolak dilakukan post-test. Jumlah subjek yang mengikuti penelitian selama 14 hari dan bersedia dilakukan pengambilan darah pre-post test adalah 15 anak untuk kelompok $\mathrm{P}_{1}$ dan 15 anak untuk kelompok $\mathrm{P}_{2}$ (Gambar 1). 


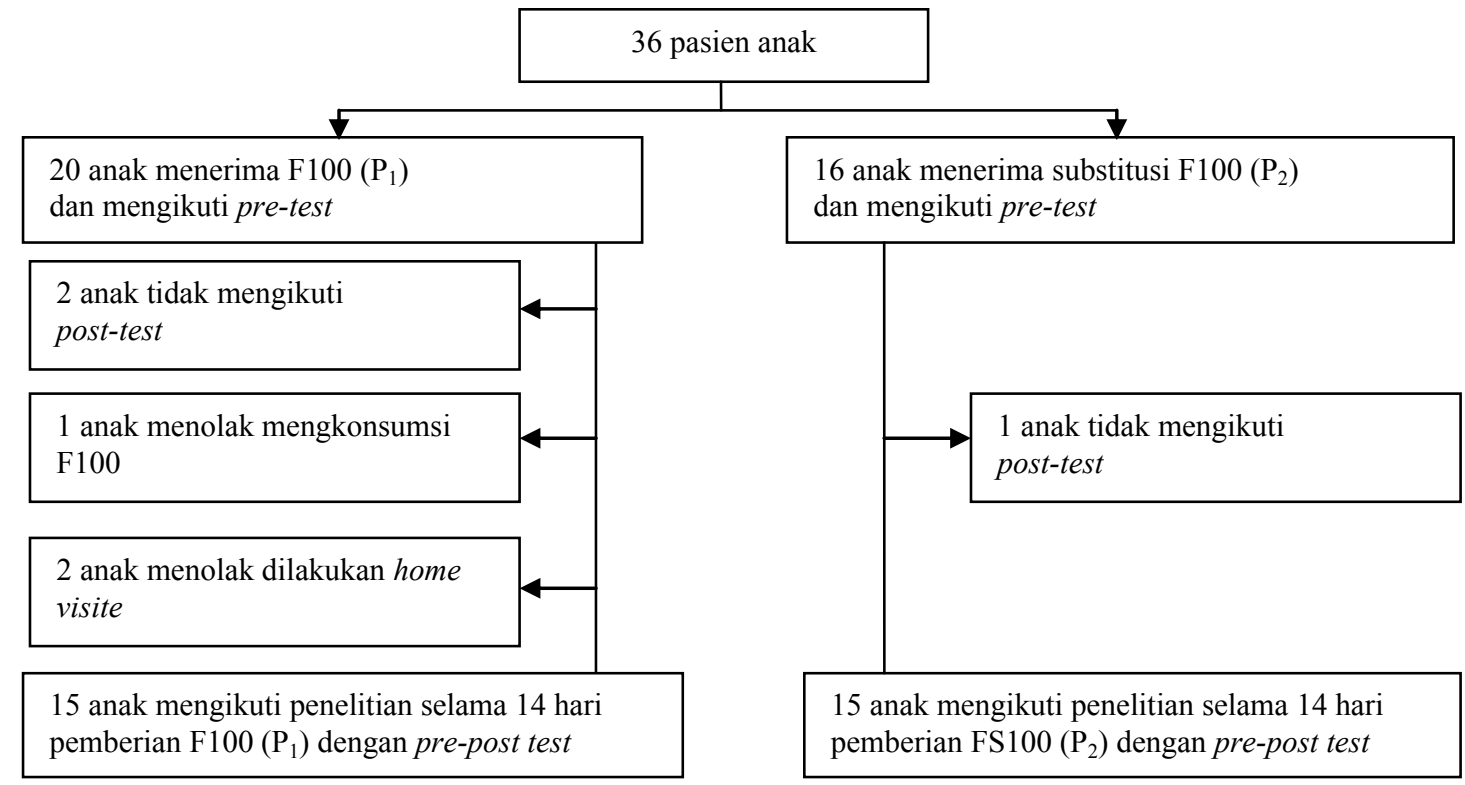

Gambar 1. Flow chart subjek penelitian

Karakteristik usia subjek penelitian ini berkisar antara 1-10 tahun. Hasil analisis univariat menunjukkan bahwa distribusi jumlah subjek penelitian yang terbanyak adalah golongan usia 7-10 tahun yaitu pada kelompok $\mathrm{P}_{2}(26,7 \%)$ dan distribusi jumlah subjek penelitian yang terkecil adalah golongan usia 4-6 tahun yaitu pada kelompok $\mathrm{P}_{1}(10 \%)$. Distribusi berdasarkan jenis kelamin menunjukkan bahwa jumlah terbanyak yaitu jenis kelamin perempuan pada kelompok $\mathrm{P}_{1}(36,7 \%)$ dan distribusi terkecil pada kelompok $\mathrm{P}_{1}$ untuk jenis kelamin laki-laki (13,3\%) (Tabel 2). Hasil uji Pearson Chi-Square menunjukkan bahwa tidak ada perbedaan proporsi yang bermakna pada golongan usia antarkelompok perlakuan $(\mathrm{p}=0,490)$. Demikian juga untuk jenis kelamin yang tidak menunjukkan perbedaan proporsi yang bermakna antar perlakuan $(\mathrm{p}=0,136)$.

Karakteristik penyakit penyerta digolongkan menjadi jenis penyakit infeksi dan jenis penyakit noninfeksi. Beberapa penyakit infeksi yang ditemukan pada subjek penelitian yaitu dengue haemorhagic fever (DHF), pneumonia, dan faringitis. Penyakit non-infeksi yang diderita subjek penelitian yaitu epilepsi dan penyakit jantung bawaan. Hasil analisis univariat menunjukkan bahwa jenis penyakit infeksi ditemukan terbanyak pada subjek dalam kelompok $\mathrm{P}_{2}(33,3 \%)$ (Tabel 2). Hasil analisis Pearson Chi-Square hubungan antara penyakit penyerta dengan perlakuan menunjukkan bahwa tidak
Tabel 2. Karakteristik subjek penelitian

\begin{tabular}{lcc}
\hline \multicolumn{1}{c}{ Variabel } & $\begin{array}{c}\mathbf{P}_{1} \\
(\mathbf{n}=\mathbf{1 5})\end{array}$ & $\begin{array}{c}\mathbf{P}_{2} \\
(\mathbf{n}=\mathbf{1 5})\end{array}$ \\
\hline Usia (tahun) & & \\
$\quad 1-3$ & $6 / 30$ & $3 / 30$ \\
$4-6$ & $3 / 30$ & $4 / 30$ \\
$\quad 7-10$ & $6 / 30$ & $8 / 30$ \\
$\quad$ Jenis kelamin & & \\
$\quad$ Laki-laki & $4 / 30$ & $8 / 30$ \\
$\quad$ Perempuan & $11 / 30$ & $7 / 30$ \\
Penyakit penyerta & & \\
$\quad$ Infeksi & $9 / 30$ & $10 / 30$ \\
$\quad$ Non-infeksi & $6 / 10$ & $5 / 10$ \\
Status gizi (BB/PB) & & \\
$\quad$ Kurang (z skor <-2SD - >-3 SD) & $11 / 30$ & $12 / 30$ \\
$\quad$ Buruk (z skor >-3 SD) & $4 / 30$ & $3 / 30$ \\
\hline
\end{tabular}

Keterangan: $\mathrm{P}_{1}=$ kelompok perlakuan F100;

$$
\mathrm{P}_{2}=\text { kelompok perlakuan FS100 }
$$

ada perbedaan proporsi yang bermakna pada penyakit penyerta antar perlakuan $(\mathrm{p}=0,705)$.

Rerata kadar protein serum total dan kadar albumin pre-test (sebelum intervensi) pada kelompok $\mathrm{P}_{1}$ berturut-turut sebesar 7,15 $\pm 0,89 \mathrm{mg} / \mathrm{dl}$ dan 3,79 $\pm 0,48$ $\mathrm{mg} / \mathrm{dl}$ sedangkan pada kelompok $\mathrm{P}_{2}$ berturut-turut

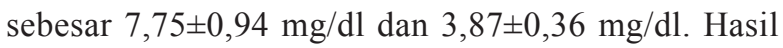
analisis menunjukkan bahwa tidak terdapat perbedaan bermakna rerata kadar protein serum total pre-test antara 
Tabel 3. Kadar protein serum total dan albumin serum (post-test)

\begin{tabular}{lccccc}
\hline & n & Rerata & SD & t & p \\
\hline Kadar protein & & & & & \\
serum total (mg/dl) & & & & & \\
$\quad P_{1}$ & 15 & 8,24 & 0,70 & $-1,201$ & 0,240 \\
$\quad P_{2}$ & 15 & 8,59 & 0,87 & & \\
Kadar albumin & & & & & \\
serum (mg/dl) & & & & & \\
$\quad P_{1}$ & 15 & 4,47 & 0,57 & $-1,290$ & 0,774 \\
$P_{2}$ & 15 & 4,52 & 0,41 & & \\
\hline
\end{tabular}

Keterangan: $\mathrm{P}_{1}=$ kelompok F100; $\mathrm{P}_{2}=$ kelompok FS100

Tabel 4. Asupan energi dan zat gizi (post-test)

\begin{tabular}{lccccc}
\hline Persentase (\%) & n & Rerata & SD & t & p \\
\hline Energi & & & & & \\
$\quad \mathrm{P}_{1}$ & 15 & 99,93 & 4,99 & 0,912 & 0,370 \\
$\mathrm{P}_{2}$ & 15 & 97,27 & 5,17 & & \\
Protein & & & & & \\
$\quad \mathrm{P}_{1}$ & 15 & 102,00 & 5,68 & 0,992 & 0,330 \\
$\mathrm{P}_{2}$ & 15 & 98,53 & 7,29 & & \\
Lemak & & & & & \\
$\mathrm{P}_{1}$ & 15 & 102,73 & 6,87 & 0,813 & 0,423 \\
$\mathrm{P}_{2}$ & 15 & 99,33 & 7,67 & & \\
Karbohidrat & & & & & \\
$\mathrm{P}_{1}$ & 15 & 106,60 & 6,47 & 0,965 & 0,574 \\
$\mathrm{P}_{2}$ & 15 & 101,43 & 9,40 & & \\
\hline
\end{tabular}

Keterangan: $\mathrm{P}_{1}=$ kelompok F100; $\mathrm{P}_{2}=$ kelompok FS100

Tabel 5. Koefisien korelasi asupan zat gizi dengan kadar protein serum total dan kadar albumin serum

\begin{tabular}{lccc}
\hline & $\mathbf{R}$ & $\mathbf{r}^{2}$ & $\mathbf{p}$ \\
\hline $\begin{array}{l}\text { Protein serum total } \\
\text { akhir }\end{array}$ & & & \\
$\quad$ Energi & $-0,196$ & 0,004 & 0,299 \\
$\quad$ Protein & $-0,157$ & 0,002 & 0,407 \\
$\quad$ Lemak & $-0,273$ & 0,021 & 0,145 \\
$\quad$ Karbohidrat & $-0,124$ & 0,015 & 0,235 \\
Albumin serum akhir & & & \\
$\quad$ Energi & $-0,146$ & 0,021 & 0,441 \\
$\quad$ Protein & $-0,154$ & 0,024 & 0,416 \\
$\quad$ Lemak & $-0,059$ & 0,003 & 0,755 \\
$\quad$ Karbohidrat & $-0,105$ & 0,011 & 0,979 \\
\hline
\end{tabular}

$\mathrm{P}_{1}$ dan $\mathrm{P}_{2}$ (varian kedua kelompok perlakuan sama, $\mathrm{p}=0,083$ ). Demikian juga dengan kadar albumin serum pre-test yang tidak menunjukkan perbedaan bermakna antara kelompok $\mathrm{P}_{1}$ dan $\mathrm{P}_{2}(\mathrm{p}=0,629)$. Analisis bivariat dengan menggunakan uji unpaired t-test dilakukan untuk menentukan ada atau tidaknya perbedaan kadar protein serum total dan kadar albumin serum post-test (setelah intervensi) antarkelompok. Hasil uji unpaired t-test menunjukkan bahwa tidak terdapat perbedaan rerata kadar protein serum total antara kelompok $\mathrm{P}_{1}$ dan $\mathrm{P}_{2}$ $(\mathrm{p}=0,240)$. Demikian juga dengan rerata kadar albumin serum post-test yang tidak menunjukkan perbedaan bermakna $(\mathrm{p}=0,774)$ (Tabel 3).

Asupan energi dan zat gizi diperoleh dari konversi asupan makanan ke dalam energi dan zat gizi selama 14 hari pengamatan, baik dengan menggunakan metode visual comstock untuk makanan dari RS maupun recall makanan 24 jam yang meliputi makanan yang disajikan oleh RS, pemberian F100 atau FS100, makanan dari luar RS, dan makanan yang dikonsumsi di rumah yang diobservasi saat dilakukan home visite. Hasil uji unpaired t-test menunjukkan bahwa tidak terdapat perbedaan rerata asupan energi, protein, lemak, dan karbohidrat antara kelompok $\mathrm{P}_{1}$ dan $\mathrm{P}_{2}$ (varian kedua kelompok perlakuan sama) (Tabel 4).

Koefisien korelasi digunakan untuk menjelaskan derajat hubungan linier antara dua variabel numerik. Derajat keeratan hubungan antara asupan zat gizi dengan kadar protein serum total dan kadar albumin serum menunjukkan hubungan yang lemah $(\mathrm{r}=0,00-0,25)$. Berdasarkan hasil uji statistik diperoleh hubungan yang tidak bermakna antara asupan zat gizi dengan kadar protein serum total dan kadar albumin serum $(\mathrm{p}>0,05)$ (Tabel 5). Analisis multivariat dengan regresi linier untuk mengetahui asupan energi dan zat gizi yang paling berpengaruh terhadap kadar protein serum total dan kadar albumin serum tidak dilakukan pada penelitian ini karena menurut analisis bivariat tidak ada data yang mempunyai nilai $p$ kurang dari 0,25 .

\section{BAHASAN}

Makanan formula sebagai makanan pelengkap yang terbuat dari bahan nabati, cukup mendukung pemenuhan kebutuhan energi dan zat gizi (2). Hasil penelitian menunjukkan bahwa pengenceran dari formula campuran yang dimasak kemungkinan mempunyai kandungan energi dan zat gizi yang kurang padat disamping dipengaruhi oleh kemampuan kapasitas lambung bayi atau anak dalam mengonsumsi makanan cair. FS100 terdiri dari campuran tepung tempe, gula, 
minyak, dan elektrolit yang bertujuan untuk memberikan asupan nutrisi seimbang bagi kelompok rentan yang membutuhkan nutrisi protein tinggi (16\% total kalori). Kualitas nilai gizi konsumsi makanan ditingkatkan melalui formula substitusi dengan mengganti susu skim dengan tepung tempe yang mengandung beberapa zat gizi mikro yang penting (zat besi dan zink).

Kadar protein tertentu dalam serum digunakan sebagai indikator evaluasi status protein pada beberapa penelitian. Pengukuran kadar albumin serum digunakan sebagai salah satu indikator karena besarnya jumlah albumin dalam susunan protein tubuh $(60 \%$ dalam cairan ekstravaskuler), dengan masa paruh waktu yang relatif lama (18-19 hari) (14,15). Terjadi peningkatan kadar protein serum total dan kadar albumin serum selama 14 hari pemberian makanan (dengan jumlah protein sebesar $16 \%$ total energi) pada kelompok $\mathrm{P}_{1}$ berturut-turut sebesar $1,09 \pm 0,46 \mathrm{mg} / \mathrm{dl}$ dan $0,68 \pm 0,31 \mathrm{mg} / \mathrm{dl}$. Sementara itu, pada kelompok $\mathrm{P}_{2}$ diperoleh peningkatan kadar protein serum total sebesar $0,84 \pm 0,30 \mathrm{mg} / \mathrm{dl}$ dan kadar albumin serum sebesar 0,66 $\pm 0,24 \mathrm{mg} / \mathrm{dl}$. Penelitian di Bangladesh (11) menunjukkan peningkatan kadar albumin serum yang bermakna setelah pemberian diit tinggi protein ( $15 \%$ total energi) dan diit standar (7,5\% total protein) selama 21 hari. Terjadi peningkatan kadar protein serum total sebesar $0,81 \pm 0,69 \mathrm{mg} / \mathrm{dl}$ dan kadar albumin serum sebesar 0,70 $\pm 0,60 \mathrm{mg} / \mathrm{dl}$ untuk diit tinggi protein sedangkan pada diit standar diperoleh hasil peningkatan kadar protein serum total sebesar $0,39 \pm 0,57 \mathrm{mg} / \mathrm{dl}$ dan peningkatan kadar albumin serum sebesar $0,52 \pm 0,49 \mathrm{mg} / \mathrm{dl}$.

Pemberian formula F100 maupun FS100 memberikan asupan 34-39\% dari kebutuhan energi per hari dan $41-48 \%$ dari total kebutuhan protein yang diberikan setiap hari sebagai makanan tambahan disamping makanan utama dan selingan. Persentase protein formula berada di atas kecukupan protein berdasarkan golongan usia yaitu $36-40 \%$ dari total kecukupan protein. Beberapa penelitian telah mengevaluasi pemberian formula campuran tinggi protein pada beberapa variabel outcome ukuran kesehatan beserta daya terima formula tersebut pada beberapa kelompok subjek penelitan. Penelitian tersebut menggunakan standar ukuran formula campuran yang menganjurkan $25 \%$ dari total asupan makanan untuk fase rehabilitasi (2). Perubahan kadar protein serum total dalam penelitian ini relatif kecil meskipun menunjukkan ada peningkatan. Selain itu, pemberian formula juga dapat memenuhi asupan protein tinggi. Hal tersebut terjadi karena adanya perubahan secara terus menerus protein dalam tubuh (hidrolisis dan katabolisme protein pada anak dengan malnutrisi dan penyakit penyertanya) menjadi komponen asam amino yang digunakan untuk pertumbuhan dan perbaikan jaringan tubuh (protein turnover) yang berlangsung singkat sehingga menyebabkan kecilnya jumlah cadangan protein tubuh yang diperoleh dari asupan makanan tinggi protein (16).

Rerata kadar protein serum total dan kadar albumin serum post-test berdasarkan hasil uji statistik tidak menunjukkan perbedaan bermakna antarkelompok (varian kedua kelompok perlakuan sama). Setelah mengonsumsi makanan sumber protein, influks asam amino menyebabkan peningkatan sintesis protein dalam hati dan otot serta peningkatan serum albumin (17). Pemberian diit tinggi protein meningkatan penyerapan asam amino dari intestinal dan peningkatan sintesis albumin dan protein otot, hal ini menyebabkan peningkatan cadangan asam amino akibat mengonsumsi diit tinggi protein. Peningkatan kualitas protein menguntungkan selain digunakan sebagai protein yang mendukung pertumbuhan maksimal pada bayi atau anak-anak, juga untuk alasan metabolik yang dapat mengurangi keadaan surplus nitrogen yang tidak efisien dalam metabolisme protein (2).

Beberapa penelitian tentang evaluasi kualitas protein dalam makanan, sering ditemukan bahwa rendahnya asupan nitrogen berkorelasi dengan penurunan kadar albumin serum dan penurunan berat badan. Sementara itu, pemenuhan asupan kalori yang cukup meskipun asupan protein kurang, dapat meningkatkan kadar albumin serum. Hal tersebut menunjukkan bahwa terjadi pemeliharaan komposisi tubuh yang berasal dari penggunaan sumber energi selain protein. Asupan energi yang memenuhi kebutuhan basal, meskipun tidak cukup dalam peningkatan berat badan, adanya perubahan kadar albumin serum kemungkinan disebabkan oleh kualitas dan kuantitas protein yang cukup.

Keeratan hubungan yang kuat dan bermakna antara kadar protein serum total dan kadar albumin serum ditunjukkan pada penelitian yang dilakukan pada 41 anak 
malnutrisi dengan infeksi dan diare $(\mathrm{r}=0,947 ; \mathrm{p}=1,4 \mathrm{x}$ $\left.10^{-9}\right)$. Hal tersebut menunjukkan bahwa pengukuran status protein dengan menggunakan kadar protein total serum dan kadar albumin dapat menggambarkan perbaikan status gizi secara biokimiawi (18). Proses hidrolisis dan degradasi protein tubuh menjadi protein khusus yang mempunyai karakteristik tertentu sebagai protein tubuh. Albumin merupakan protein tubuh yang paling banyak dengan masa paruh waktu 19 hari, memiliki kesempatan paling besar untuk mengalami degradasi. Relevansi tingkatan degradasi albumin pada malnutrisi menunjukkan penggunaan albumin dalam sintesis protein di hati dan menyebabkan $50 \%$ penurunan konsentrasi dalam darah selama periode 19 hari (16).

Penelitian ini tidak bisa menganalisis asupan energi dan zat gizi yang paling berpengaruh terhadap kadar protein serum total dan kadar albumin serum karena kecilnya perubahan kadar protein serum total dan kadar albumin meskipun terjadi peningkatan kuantitas energi dan protein. Berbeda dengan penelitian pada bayi dan anak malnutrisi di Peru yang menunjukkan bahwa kadar serum albumin dipengaruhi oleh asupan energi dan protein, diasumsikan bahwa defisiensi kalori dalam jangka panjang menyebabkan penggunaan asam amino dari otot dan organ internal sebagai bahan dalam sintesis albumin (18).

\section{SIMPULAN DAN SARAN}

Jumlah rerata asupan energi, protein, lemak, dan karbohidrat menunjukkan tidak terdapat perbedaan yang bermakna antara pemberian makanan F100 dan FS100 pada anak dengan gizi kurang. Demikian pula dengan rerata kadar protein serum total dan kadar albumin serum yang tidak menunjukkan perbedaan bermakna antara pemberian makanan F100 dan FS100 pada anak dengan gizi kurang. Terdapat hubungan yang tidak bermakna antara asupan energi dan zat gizi dengan kadar protein serum total dan kadar albumin serum. Derajat keeratan hubungan antara asupan energi dan zat gizi dengan kadar protein serum total dan kadar albumin serum menunjukkan hubungan yang lemah.

Metode pengolahan tepung tempe maupun FS100 cukup sederhana sehingga dapat dilakukan di RS maupun di tingkat rumah tangga sebagai alternatif pengganti F100 pada pasien yang tidak dapat atau tidak mau minum susu atau sebagai makanan tambahan fase rehabilitasi saat pasien keluar dari RS. FS100 dapat diberikan pada pasien sesuai dengan terapi diit yang ditetapkan karena formula tepung tempe terbukti mempunyai beberapa kelebihan dalam mutu (viskositas), kepadatan energi, dan mengandung nilai gizi yang tinggi (protein dan lemak). Perlu dilakukan penelitian lanjutan pemberian FS100 sebagai formula tumbuh kejar pada anak terhadap peningkatan berat badan dan penelitian potensi efek negatif zat anti gizi yang terkandung dalam FS100 (asam fitat) untuk mengetahui efek negatif organoleptik dan faktor lainnya.

\section{RUJUKAN}

1. WHO. Management of severe malnutrition: a manual for physicians and other senior health workers. Geneva: WHO Library Cataloguing in Publication Data; 1999.

2. Hoppe C, Gregers S, Jacobsen A, Molgaard C, Friis H, Sangild PT, Michaelsen KF. The use of whey or skimmed milk powder in fortified blended foods for vulnerable groups: a literature review. J Nutr 2008;138(1):145S-61S.

3. Ferguson EL, Briend A, Darmon N. Can optimal combination of local foods achieve the nutrient density of the F100 catch-up diet for severe malnutririon?. J Pediatr Gastroenterol Nutr 2008;46(4):447-52.

4. Brewster DR, Manary MJ, Menzies IS, Henry RL, O'Loughlin EV. Comparison of milk and maize based diets in kwashiorkor. Arch Dis Child 1997;76(3):242-8.

5. Khanum S, Ashworth A, Huttly SRA. Growth, morbidity, and mortality of children in Dhaka after treatment for severe malnutrition: a prospective study. Am J Clin Nutr 1998;67(5):940-5.

6. Greco L, Balungi J, Amono K, Iriso R, Corrado B. Effect of low-cost food on the recovery and death rate of malnourished children. J Pediatr Gastroenterol Nutr 2006;43(4):512-7.

7. Diop el HI, Dossou NI, Ndour MM, Briend A, Wade S. Comparison of the efficacy of a solid ready-to-use food and a liquid, milk-based diet for the rehabilitation of severely malnourished children: a randomized trial. Am J Clin Nutr 2003;78(2):302-7.

8. Ciliberto MA, Sandige H, Ndekha MJ, Ashorn P, Briend A, Ciliberto HM, Manary MJ. Comparison of home-based therapy with ready to use therapeutic food with standard therapy in treatment of malnourished Malawian children: a controlled, clinical effectiveness trial. Am J Clin Nutr $2005 ; 81(4): 864-70$. 
9. $\quad$ Sandige H, Ndekha MJ, Briend A, Ashorn P, Manary MJ. Home-based treatment of malnourished Malawian children with locally produced or imported ready-to-use-food. J Pediatr Gastroenterol Nutr 2004;39(2):141-6.

10. Lemeshow S, Hosmer Jr DW, Klar J, Lwanga SK. Besar sampel dalam penelitian kesehatan. Pramono D (Alih bahasa). Yogyakarta: Gadjah Mada University Press; 1997.

11. Kabir I, Malek MA, Mazumder RN, Rahman MM, Mahalanabis D. Rapid catch-up growth of children fed a high protein diet during convalescence from shigellosis. Am J Clin Nutr 1993;57(3):441-5.

12. Willet W. Nutrition epidemiology. 2nd ed. New York: Oxford University Press; 1998.
13. Winarno FG. Kimia pangan dan gizi. Jakarta: PT. Gramedia Pustaka Utama; 1993.

14. Young VR, Marchini JS, Cortiella J. Assessment of protein nutritional status. J Nutr 1990;120(Suppl 11):1496-502.

15. Peters T. All about albumin: biochemistry, genetics, and medical. London: Academic Press; 1996.

16. Brody T. Nutritional biochemistry. 2nd ed. London: Academic Press; 1999.

17. Linder MC. Biokimia nutrisi dan metabolisme dengan pemakaian secara klinis. In: Parakkasi A (Alih bahasa). Jakarta: Penerbit UI-Press; 1992.

18. Baertl JM, Placko RP, Graham GG. Serum protein and plasma free amino acids in severe malnutrition. Am J Clin Nutr 1974;27(7):733-42. 